\title{
Juridical Analysis of the Impact of the Law for Companies Conducting Worker Diploma Detention
}

\author{
Muhammad Mahendra Abdi ${ }^{1}$, Fakhruddin Razi ${ }^{2}$ \\ $\left\{\underline{\text { mahendraabdi@unism.ac.id }}\right.$, fakhruddinrazy@unism.ac.id $\left.{ }^{2}\right\}$ \\ ${ }^{1}$ Sari Mulia University, Banjarmasin \\ *mahendraabdi@unism.ac.id
}

\begin{abstract}
The mandate in the law is also in line with article 27 paragraph (2) of the 1945 Constitution of the Republic of Indonesia which reads "Every citizen has the right to work and a decent living for humanity". The purpose of this study is to find out how the legality of the work agreement for the detention of diplomas carried out by companies with workers, and the legal implications for companies to hold diplomas. The research in this paper uses the normative legal method with the nature of the research description that is giving an explanation or description of the legality of the employment agreement if there is a detention of a diploma and corporate legal liability that eliminates the employee's diploma. The law used is legal material, namely the Civil Code, Law Number 13 of 2003 concerning Manpower and secondary legal material from several literatures. According to the results of this study indicate that the first: The contents / class in the employment agreement the detention of diplomas against workers does not have binding legal force. The second is the legal impact on companies carrying out the detention of their employees' diplomas, that is, companies may be subject to administrative sanctions as stipulated in Law Number 13 of 2003 concerning Manpower in article 190 paragraph (1) and (2)
\end{abstract}

Keywords : implications, diploma .

\section{Introduction}

Indonesia is a very large country with a population of approximately 260 million people, Indonesia is ranked fourth most populous country in the world after China (1.42 billion people), India (1.37 billion people), and the United States at (328 million people). Indonesia is currently enjoying a demographic bonus period where the population of productive age is more than the unproductive age, which is more than $68 \%$ of the total population.

Number of reproductive age have an impact also on the needs of life, with modern hi life needs is the future human productive derung to search for a decent life and air quality, one way to needed a decent living and quality then balanced with a good job anyway.

Livelihoods and jobs cannot be separated from the name of education, the more the work is strategic and bona fide both government and private agencies, then the requirements for getting a job must be balanced with qualified educational qualifications. Qualified education qualifications 
are balanced with a paper that reads diploma. This principle will be one of the important requirements for someone in applying for a job according to their respective fields.

A diploma is a letter of graduation stating that someone has completed and successfully learned a level of knowledge and learning. Diplomas are securities and are useful for someone in finding work. Nowadays most companies always require to attach original certificates when applying for a job as proof that we really fit the qualifications needed by the company.

The case that often occurs at this time is the number of companies that hold the original permission of prospective employees who want to work at the company. The reason most widely expressed to employees in the detention of this permit is commitment to work, so this is a big concern for employees who want to work in a company. concerns even this is not really a strong foundation against employees because of the Indonesian constitution that stipulated in article 1, paragraph (3) of the U ndang the Republic of Indonesia said that Indonesia is a country of law, the concept of rule of law state that all the order of statehood must be grounded in the law applicable (positive law) and have been finalized in the form of regulations .

\section{Method}

This research uses normative legal research method. This research uses normative legal research. Normative legal research focuses on positive legal norms in the form of laws and regulations that have relevance to the problem and this research, also uses secondary data in the form of other legal books that have relevance to the problem written.

This research data collection method is by means of a literature study, which is a research conducted by collecting data relating to the form of legal liability of a company that eliminates the diploma of its workers. Overall data obtained from various sources are collected into one and complete, then arranged in a organized and gradual manner so that in the end the analysis can be done on the data. The method used in analyzing data is descriptive qualitative. Descriptive, namely narrative describing an existing problem or phenomenon. Qualitative that is to analyze narratively about a problem or phenomenon systematically. In drawing conclusions, reasoning processes or procedures are used deductively. This means that the writer in describing conclusions with a flow of thought of a general nature then draws conclusions to specific things

\section{Discussion}

The case of detention izasah as a guarantee of professionalism in working as a form of work ethic guarantees delegated to employees is not normal, the detention of this diploma is the detention of property rights over the collateral object because this diploma is used as collateral in a work agreement between the company and the worker. Law Number 13 of 2003 concerning Manpower indeed does not have rules that enforce or require companies to hold a diploma of their work, there are only employment contracts that can be made based on an agreement between the company and the worker .

Seeing from the reference to the law, one of the legal requirements for an agreement in Article 1320 of the Civil Code is the agreement of those who bind themselves, the ability to make an agreement, a certain thing, and a legal cause. Viewed dar i requirement s ahnya such an agreement 
then adany a agreement between both $\mathrm{p}$ ihak is the foundation step piha $\mathrm{k}$ companies impose detention as a form of guarantee worker diploma employment contract is legally valid.

Another thing that causes the detention of diplomas as a form of legal employment contract due to the absence of strict government regulations regarding the prohibition of the use of diplomas as guarantees of professional work.

Look further and s eksama about securing a diploma by the company, almost certainly the number of workers who do not feel comfortable by the condition of the company, while recruiting new workers would more take time, effort, and cost to mela tih workers that will be placed positioning empty, therefore, there are some companies impose diploma detention .

Actually the company does not need to hold a diploma in a work agreement that has been agreed or that has been made, because the employment contract that was made also there are consequences that must be accepted by prospective new workers, this is why workers must be careful in advance about the contents of the work agreement, if the worker has signed, the prospective worker has also agreed to the contents in the employment contract. And one thing that must be paid attention to by workers is in Law No. 13 of 2003 concerning Labor in Article 54 paragraph (1) of an employment agreement made in writing must at least contain "a. name, company style, and type of business, b. name, sex, age and address of the worker / laborer, c . job title or type of work, d. place of work, e. amount of wages and method of payment, f. terms of work containing the rights and obligations of employers and workers, g, began and the period of validity of the work agreement, $\mathrm{h}$, place and date of employment agreements are made, and $i$, the signature of the parties in the employment agreement ".and in Article 54 Paragraph (2) Provisions in an employment agreement as referred to in paragraph (1) letters e and $\mathrm{f}$, may not conflict with company regulations, collective work agreements, and applicable laws and regulations . (3) A work agreement referred to in paragraph (1) is made of at -kurangn ya in 2 (two), which has the same legal force, as well as workers / laborers and employers each receive 1 (one) work agreement.

According to Civil Code Article 1365 , it is a legal violation is unlawful act committed by a person who because of his fault has caused losses for others. Jurisprudence recognizes three categories of acts against the law, namely: acts against the law on purpose, acts against the law without error, and acts against the law due to negligence.

Thus each action violates both intentionally and unintentionally of a violating nature. Means that the element of intent and negligence here has been fulfilled. Then what is meant by law in the aforementioned Article is all provisions and regulations - rules or methods, both written and unwritten and everything that is considered as law. It means that what is violated is law and what is seen or considered as law, such as laws, binding customs, judges' decisions and so on. Furthermore, for this violation of the law to be said to have carried out acts against the law, the consequences of violating the law must bring harm to other parties. Because there are times when a violation of the law does not have to bring harm to others. Thus between the sentence "every act violates the law", can not be separated from one another, even must be in line in realizing the understanding of the act against the law

The elements of acts against the law according to article 1365 of the Civil Code include: The existence of an act and the act is against the law, There is an error, There are losses to the victim, and a and a causal relationship between the act and loss. According to Marheinis Abdulhay that "the person found guilty is a legal subject or person (person), because the subject is recognized as 
having rights and obligations." Means that based on the statement declared guilty is a legal subject that is declared to have committed acts against the law is also a legal subject, the reason being the subject the law has rights and obligations. Person dictionary of legal terms are "subject, the subject of legal relations, private person or legal entity in such position is authorized to take legal action". Means that include those said or classified as subjects in the view of the law are individuals and legal entities. Then what is meant by legal subject is an individual or legal entity in his position as a subject having the authority to take legal actions. Therefore, those who are subject to acts against the law are individuals or legal entities that have committed acts or actions that are against the law

In the case of a loss of workers' certificate in a company, this is closely related to compensation, this is due to a default in an agreement with what is known as compensation as a result of unlawful acts (onrechtmetige daad). The difference between breach of contract and the act against the law is that in breach of contract there is a term of subpoena, namely the determination of negligence referred to in Article 1274 of the Civil Code. Thus the default occurs if one of the parties or the debtor, for example after the determination of this negligence he still does not perform or fulfill his expectations, the debtor can be called a default. In addition, in general tort actions have caused an engagement made by both parties, both the engagement and the engagement which is based on agreements arising out of laws While acts against the law there is no determination of negligence or advance warning.

According to the applicable provisions to date namely Law No. 13 of 2003 Article 1 paragraph 15 employment relations are relations between employers and workers or laborers based on work agreements, which have elements of work, wages, and orders. From the basis of the employment relationship, it can be seen that the employment relationship is the foundation between the worker and the employer to initiate and regulate a right and obligation in the work to be carried out after the employment relationship is made .

Based on the provisions of article 52 paragraph 1, paragraph 2, and paragraph 3 of Law Number 13 of 2003, the conditions for legal employment are: agreement between the two parties, the ability to carry out legal actions, the existence of the work promised, and the object of work provided may not contrary to public order, morality, and legislation that Berla me. These four conditions are cumulative which means that all of them must be fulfilled before the agreement can be valid. Terms of agreement between the two parties and the ability or ability of both parties to make agreements in civil law are referred to as subjective conditions because it involves the person making the agreement, while the terms of the work promised and the work promised must be halal is called an objective condition because it involves the object of the agreement . If the objective conditions are not fulfilled, then the agreement is null and void, meaning that the agreement was considered to have never existed.

According to the Big Indonesian Dictionary (KBBI) responsibility is a condition where it is obliged to bear everything, so it is obliged to bear, assume responsibility, bear everything or give responsibility and bear the consequences. In the legal dictionary, responsibility is a necessity for a person to carry out what is required of him. According to the law, responsibility is a result of the consequences of a person's freedom of conduct related to ethics or morals in carrying out an act

In the civil law there are two terms overall responsibility for late, namely liability and responsibility, liability is a legal term widely to designate almost all forms of risk or responsibility, including all the characters the rights and obligations of such damages, 
threat, crime, cost, or the circumstances of which creates duty to implement the law. Responsibility means things that can be accounted for by an obligation, and includes decisions, skills, abilities, and abilities including obligations for the law implemented.

The form of legal liability according to Article 1365 of the Civil Code which reads: "Every act that violates the law, which brings harm to others, obliges the person who because of the wrong to issue the loss, compensates for the loss." This Article is an article popularly related to breaking the law to compensate for the loss suffered by a person, the responsibility to make compensation payments can only be done if the person who violates the law is someone who is capable of being legally responsible / capable of law.

Article 1366 of the Civil Code "Every person is responsible not only for losses caused by his actions, but also for losses due to negligence." This article shows the extent of responsibility for people who commit acts that violate the law so that he is not only responsible for losses due to the consequences arising from an act that is actively done, but also responsible for losses due to negligence .

Article 1367 of the Civil Code which reads; "A person is not only responsible for the loss caused by his own actions, but also for the loss caused by the actions of those who are responsible for or caused by the goods under his supervision." The responsibility set forth in this article is the responsibility for the mistakes of others under his responsibility. So in fact this article can be said to hold risk responsibility, or responsibility without error, even though the risk responsibility is limited only if the person who made the mistake resulting in the loss is a person under his responsibility.

Based on the results of the citation of the articles above, in general it gives a big picture of the scope of the scope of the consequences of an unlawful act that has legal consequences for the perpetrators and those who have legal relations in the form of an employment agreement that causes unlawful acts. So the consequences that the bul team from an act against the law will be realized in the form of compensation

Replacement of losses as a result of an unlawful act, seb agaiman a discussed above, the replacement of material and immaterial losses often practice such replacement with money, or equated with money in addition to their demands replacement of object or objects are considered to have been damaged.

Detention of a diploma by this company results in various kinds of problems, one of which is the loss of a worker certificate or damage to a worker certificate. The loss of workers diploma make a major impact for the owner of a diploma dikarena right certificate can only be issued once and can not be reprinted. This has become the anxiety of workers to submit diplomas, and one side of prospective workers also want to work in the field of interest. The low power possessed by workers makes a big challenge for the government. The government should have started to make a firm action on companies that hold diplomas from their workers.

\section{Conclusion}

Based on the analysis of the discussion above, the authors conclude that the legality made in the employment agreement in which there is a class of legal diploma submission according to the law, however, retaining the diploma by the company is a form of mistrust of the company to 
prospective workers, and also the company does not sure what is made in the work agreement that has been made in the form of a work contract, even though the work agreement that has been fulfilled the elements intended by law then the agreement is valid and binding, therefore, the author gives a message so that there is no detention diploma for prospective workers.

When there hilanya certificates conducted by the company, it can be subject to Article 1365, Article 1366 and Article 1367 kit ab laws OF civil law, because the company resulted in a loss for o rang another. Article 1365 can be used because the company is obliged to be responsible for losses caused by negligence or carelessness. In the Civil Code in article 1367 the company is also responsible for the people under its supervision. In civil law laws there are two compensation, namely compensation in the form of material and immaterial. In material form, it can be in the form of monetary compensation, and the material liability is compensation, in the form of a letter to replace a diploma.

\section{References}

[1] Abdulkadir Muhammad, 2002, Lawyers Association, Alumni, Bandung.

[2] Abdulkadir Muhammad, 2010, Indonesian Corporate Law, Citra Aditya Bakti, Bandung.

[3] Satrio, J., 2002, Law of Agreement, Citra Aditya Bakti, Bandung.

[4] Sehat Damanik, 2004, Labor Procedure Law, Dss Publishing, Jakarta.

[5] Setiawan, R., 2007, Principles of Civil Law, Bina Cipta, Bandung.

[6] Yahya Harahap, M., 2002, Legal Aspects of Agreement, Alumni, Bandung.

[7] Code of Civil law The 1945 Constitution of the Republic of Indonesia

[8] Law Number 13 of 2003 concerning Manpower 